\title{
Analysis of Measles Vaccination Refusal on Social Media (Facebook) among Anti-Vaccine Communities in Indonesia
}

\author{
Dwi Meilani $^{1}$, Evi Martha ${ }^{2}$, Hadi Pratomo2*, Indah Jamiatun Hasanah ${ }^{2}$, Yoslien Sopamena ${ }^{2}$, Somporn Rungreangkulkij ${ }^{3}$ \\ ${ }^{1}$ Graduate Student of Faculty of Public Health, Universitas Indonesia, Depok, Indonesia \\ ${ }^{2}$ Department of Health Education and Health Promotion, Faculty of Public Health, Universitas Indonesia, Depok, Indonesia \\ ${ }^{3}$ Faculty of Nursing, Khon Kaen University, Khon Kaen, Thailand
}

\begin{abstract}
Measles is one of the main causes of global mortality in the under-fives. The existence of groups that reject immunization caused a decrease in immunization coverage. Anti-vaccine messages are widely delivered on social media. Identification of vaccine rejection behavior can be used as the basis to formulate effective program strategies. The design of this study used rapid assessment procedures (RAP). The informants were from two anti-vaccine communities in the Facebook group. In-depth interviews and observations were done for data collection, and data analysis was performed using the Framework Method. The results found that determinants, such as knowledge, beliefs in health behavior and disease prevention, religion, culture, and government policies play a role in shaping informants' perceptions of vaccines and disease risks. The design factors of vaccination programs and the reliability of vaccine-producing sources were found to be inhibiting factors for informants to receive vaccines. Also, determinants like media communication, experience with vaccines, health workers' role, and lobbying by anti-vaccine groups strengthened informants' attitude who initially doubted vaccines, causing them to reject vaccines ultimately. It is suggested to the Ministry of Health to improve vaccination campaigns through social media, conduct vaccine development study, and increase health workers' knowledge related to vaccines and make their communication techniques more effective.
\end{abstract}

Keywords: anti-vaccine, social media (Facebook), vaccine hesitancy

\section{Introduction}

Measles is one of the main causes of death in children under five years old globally. ${ }^{1}$ In Indonesia, measles immunization coverage is still below the 2015 target set at over $95 \%$. The immunization coverage in 2015 was $94.7 \%$ and had decreased in $2014(92.3 \%)$ compared to $2013(97.8 \%) .^{2}$ In Indonesia, vaccination programs have been implemented since 1956 . However, national immunization coverage in 2015 was still at $86.54 \%$. This percentage has not yet reached the Strategic Plan target in 2015 of $91 \%$. Compared to immunization coverage in the period 2008-2011, the rates for the period 2012 2015 decreased and some regions in Indonesia were still experiencing outbreaks of diseases that can be prevented by immunization. ${ }^{3}$ By 2015, there were areas of the country where more than $60 \%$ of children were not vaccinated. ${ }^{4}$

One of the causes behind the decline in vaccinations in Indonesia is the presence of groups that reject immunization. ${ }^{5,6}$ This anti-vaccine community has been around since the first vaccine was discovered and so far, nothing has changed. 7,8 There are many reasons for vaccine refusal, including lack of access to regular health care, low-income families, fear-based messages, protection of individual liberties, issues around the vaccine's purity, and religious belief. ${ }^{8,9}$ Based on a research in America, the anti-vaccine message has been delivered by the anti-vaccine group community on the internet. The information conveyed by anti-vaccine groups on social media can affect one's perception about immunization, that vaccines are actually ineffective and even dangerous. ${ }^{10}$ The use of the internet to access health information has been increasing. A study in Ontario, Canada, conducted by Kata, stated that $70 \%$ of internet users' information had influenced the decision to obtain health care. ${ }^{11}$ Kelly, Jenkinson, and Ziebland, ${ }^{12}$ found that health-related websites act as peer-to-peer information channels that provide experiential information including factors like feeling supported, relationships with others, experiencing health services, and affecting behavior. Some groups may use this channel to amplify the misinformation. ${ }^{12}$ In Indonesia, the number of active monthly 
users of the social media platform, Facebook, up to January 2019, had reached $136,960,000$, which accounts for $50.1 \%$ of the entire population. ${ }^{13}$ One study conducted in Indonesia found several reasons for parents not to immunize their children. Parental reasons were categorized into three interrelated themes: belief barriers, safety concerns, trust, and misinformation issues. ${ }^{14}$ The study conducted by Kata, 11 also described that $80 \%$ of internet users use this access to search for health information online, and $16 \%$ of them were looking for information about vaccinations. Based on the study above, the internet has become one of society's primary health information sources. 15

Wahyurnani, et al., 16 in a study of community assessments of measles immunization in the Sleman Regency (Yogyakarta Special Region), the internet media were often used by citizens to search for health information, including measles immunization. The study also concluded that the decision for immunization was influenced by religious scholars' advice and medical personnel' behavior. Moreover, the presence of side effects experienced by individuals was reported. 16

In 2012, the World Health Organization (WHO) Strategic Advisory Group of Experts (SAGE) formed an immunization working group that aims to identify the vaccine's determinants of hesitancy and what efforts should be made to overcome them. The results of the SAGE Working Group study concluded that vaccine rejection behavior was influenced by three main factors, namely (1) Contextual influences such as communication and media environment, influential leaders, historical reasons, religion, culture, political reasons, lobbying (approach) by anti-vaccine groups, geographical barriers and the pharmaceutical industry, (2) Individual and group influences arising from personal vaccine perception factors such as knowledge, health system and social/peer environment, and (3) vaccine-/vaccination-specific issues. ${ }^{17}$

The purpose of this study was to analyze the determinants related to vaccine rejection behavior, including perceptions of government policies related to immunization, knowledge and beliefs related to immunization, perceived benefits, the dangers of immunization, cultural and religious barriers, and environmental factors (the influence of media, the influence of health workers and the influence of anti-vaccine group lobbying).

\section{Method}

This is a study used a qualitative study applying the Rapid Assessment Procedures (RAP). ${ }^{18-20}$ The RAP was conducted using observation and in-depth interview methods. For observation, authors had focused for two months, from June 2016 through July 2016, on group Facebook activity among members (anything posted, comments and replies, news feeds). The observation was also held directly at the house of a member of the Facebook "Stop Vaksin" group for a day. The house itself was a gathering point for group members and an alternative medicine practice owned by the host. This study was conducted on two anti-vaccine communities on the Facebook social media group, namely "Stop Vaksin di Indonesia" and "Gerakan Anti Vaksinasi dan Imunisasi/Movement Against both Vaccination and Immunization" (GAVI).

In this study, informants are eight members of the anti-vaccine Facebook group community and four key informants. The informants consisted of one informant from Islamic scholars; which divided into one informant from vaccination activists, one informant from adverse events following immunization (AEFI) working groups, and one informant from the Manager Program in the Immunization Sub-Directorate of the Directorate General of Disease Prevention and Control, Ministry of Health, Republic of Indonesia. Before data collection, informed consent was given by each informant and key informant to comply with the ethics research principles elaborated in the Helsinki Declaration. ${ }^{21}$ In addition to the anti-vaccines group members interviewed, four key informants consisted of one religious leader, one Immunization National Commission member, one general practitioner, and one program manager of the Immunization Sub-Directorate.

Data collection was conducted in June-July 2016 by the authors and trained author assistants. The sampling technique used in this study was purposive sampling. Data collection techniques used in this study were indepth interviews and observations. ${ }^{22}$ The authors visited one of the selected anti-vaccine community members. The place was a cupping treatment site, and it was a gathering place for members of the anti-vaccine community. The instrument used was semi-structured questions, and it was taken from The SAGE Working Group on Vaccine Hesitancy, ${ }^{17}$ and modified by authors. The questions contained perceptions of government policies related to immunization, knowledge, and beliefs related to immunization, perceptions of immunization benefits and dangers, and perceptions of cultural and religious barriers. This instrument has been tested on two parents who rejected vaccines, and correction has been made based on the trial. Before the data was collected (interviews and recordings), informed consent was obtained from each informant. Data analysis was done using the Framework Method. ${ }^{23-25}$

All interview results were transcribed and coded. After the transcript had been coded, researchers compared it to be developed into a thematic framework that identifies key themes and sub-themes related to research questions. Thematic frameworks were tested and refined with all transcripts to ensure that the framework includes 
all data in transcripts relevant to the study question but are not too simplistic. This procedure also ensures that the data in each sub-theme is coherent and that there are apparent differences between the sub-themes. The framework was revised in discussion with the team until all the information was able to be fit in the framework. The revised framework is shown in Table 2. The thematic framework consists of four areas: The first and second areas were perceptions of government policies related to immunization and knowledge and beliefs related to immunization. The third area was perceptions of benefits, the danger of immunization, cultural, and religious barriers. The last area was the environmental factors (the influence of the media and the anti-vaccine group lobby).

\section{Results}

There were eight informants in this study. The informants who participated in the in-depth interviews in this study were members of the Facebook social media group's anti-vaccine movement. The average age was 39 years old, and the age range was between 26 and 45 years old. The majority of them were female, and their education level ranged from senior high school to Bachelor of Science. Details of the characteristics of the informants are as shown in Table 1.

The authors also looked at some components of the Health Belief Model theory. This study indicated that the environmental factor related mostly to the media's influence, including mass media and social media. Also, knowledge and beliefs related to immunization were related to individual influence. Similarly, the perceived benefits and dangers of immunization were also included as individual influences. Social influence was represented by both cultural and religious barriers related to immunization. Detailed discussion for each issue was as follows in Table 2.

Two major issues were raised related to policies. The first issue is concerned with clear information regarding both impact and risk of immunization. The other issue was the fact that immunization was obligatory for every child. Some informants argued that the government's policies were not yet transparent, as, on the one hand, it forced and obliged the entire community to vaccinate.
However, information about the impacts and risks generated by vaccines was not delivered. They are also well-informed about coverage appointed by the WHO for every child's immunization program, even though they assumed that WHO seems to equalize everything.

Some issues discussed were knowledge of the benefits of immunization, delivery of vaccines, and perceived effectiveness of vaccination. The government has conducted various training sessions to equip health workers with information and knowledge about immunization to deliver to the community. Most of these informants have various knowledge levels regarding the vaccines' effectiveness against diseases, and they got that information from friends, books, and from their experiences. Unfortunately, an informant whose friend told her that even though her daughter has been immunized with the measles vaccine, she still caught the disease.

The informants did not question how the vaccine was administered but were more worried about its content and its consequence for the human body. Some issues of concern were also noted, for example, that the perceived danger of immunization was more significant than the perceived benefit of immunization. Also, most informants voiced concern about how either halal or haram of the vaccine source. It was likely that all these information elements were connected to their belief and religion. Most informants voiced concern about halal and haram sources regarding the benefit and danger of immunisation and cultural and religious barriers.

The environmental factor is related mostly to the media's influence, including mass media and now social media and the anti-vaccine group lobby's influence. Media such as television have contributed partial information. Informants sought information about vaccines through new media, such as social media, through testimony or others' experiences, which consequently affected their decision about immunization. Social media also provides freedom for everyone to create a group or fan page with a similar interest.

\section{Discussion}

Regarding informants' perception of government policies, it was found that some informants argued that gov-

Table 1. Characteristic of Informants, Member of Gerakan Anti Vaksinasi Facebook Group

\begin{tabular}{|c|c|c|c|c|c|}
\hline Code of Informant & Age (Years) & Sex & Occupation & Last Education & Position \\
\hline Informant $\mathrm{HN}$ & 26 & Female & Housewife & Bachelor graduate & Group's admin \\
\hline Informant IR & 32 & Female & Entrepreneur & Bachelor graduate & Member of Gerakan Anti Vaksinasi dan Imunisasi \\
\hline Informant DW & 42 & Female & Entrepreneur & Bachelor graduate & Group's admin \\
\hline Informant MA & 45 & Male & Entrepreneur & Bachelor graduate & Group's admin \\
\hline Informant BG & 44 & Male & Entrepreneur & Diploma graduate & Member of Stop Vaksin \\
\hline Informant JW & 43 & Female & Private company employee & Senior high school & Member of Stop Vaksin \\
\hline Informant NS & 42 & Female & Housewife & Senior high school & Member of Stop Vaksin \\
\hline
\end{tabular}


Table 2. Theme, Sub-Theme, and Relevant Quotations

\begin{tabular}{|c|c|c|}
\hline Theme & Sub-Theme & Quotations \\
\hline \multirow[t]{2}{*}{$\begin{array}{l}\text { Perception of government } \\
\text { policies related to immunization }\end{array}$} & $\begin{array}{l}\text { Perceived as being nontransparent } \\
\text { infomation: Impacts and Risks }\end{array}$ & $\begin{array}{l}\text { "They came to my house and forced me to polio vaccinate my child. She said, if my child } \\
\text { were infected with polio, all the village population would be infected with polio too." } \\
\text { (Informant WH) }\end{array}$ \\
\hline & $\begin{array}{l}\text { Perceived as imposing and obliging } \\
\text { all people to vaccinate }\end{array}$ & $\begin{array}{l}\text { "Well, this is actually the role of the government. Before implementing the program, they } \\
\text { must be honest about what immunization is and what vaccination is. Because all this } \\
\text { time we have seen a duping process, a process of omission." (Informant BG) } \\
\text { "Yes, the WHO has a target for children, (the vaccine) coverage up to } 90 \% \text { by } 2020 . \\
\text { I read the WHO project several times, because WHO really seems to equalize } \\
\text { everything..." (Informant HN) }\end{array}$ \\
\hline \multirow[t]{3}{*}{$\begin{array}{l}\text { Knowledge and belief related } \\
\text { to immunization }\end{array}$} & $\begin{array}{l}\text { Knowledge of: } \\
\text { - Benefits of vaccination } \\
\text { - Consequences of vaccine delivered } \\
\text { and not delivered }\end{array}$ & $\begin{array}{l}\text { "For midwives, various training. From various ways, for example, training conducted by } \\
\text { Kesehatan Ibu dan Anak (Maternal and Child Health Division), it has immunization } \\
\text { material. Training conducted by the the Directorate General of Pharmaceutical and } \\
\text { Medical Devices and pharmacies also invited the midwife coordinator. The funding } \\
\text { sources were from WHO and UNICEF. So, the training continues from various funding } \\
\text { sources. Well, we ourselves at the subdistrict of immunization, we also do the same } \\
\text { thing." (Key Informant HK) }\end{array}$ \\
\hline & $\begin{array}{l}\text { Perception of immunization } \\
\text { effectiveness against diseases }\end{array}$ & $\begin{array}{l}\text { "... I've read, the antibodies produced by the vaccine did not last long. The benefits are } \\
\text { only temporary, and it will not be worth it." (Informant HN) }\end{array}$ \\
\hline & & $\begin{array}{l}\text { "Many children are immunized against measles but still get sick from measles. I see } \\
\text { friends whose children are not vaccinated, they are actually healthy and rarely get sick." } \\
\text { (Informant WH) }\end{array}$ \\
\hline \multirow{5}{*}{$\begin{array}{l}\text { Perceived benefit and danger } \\
\text { of immunization, cultural, and } \\
\text { religious barriers }\end{array}$} & $\begin{array}{l}\text { Thought of risks and dangers } \\
\text { greater than benefits }\end{array}$ & $\begin{array}{l}\text { "For example, if by injecting children can be safe and healthy } 100 \% \text {, it's not a problem } \\
\text { for me. But the problem is the security of the content" (Informant HN) }\end{array}$ \\
\hline & $\begin{array}{l}\text { Vaccination does not guarantee } \\
\text { that children will become immune }\end{array}$ & $\begin{array}{l}\text { "Vaccines, if made from human blood, they are clearly haram especially if it's in contact } \\
\text { with pigs. Don't forget that we not only have a problem with halal-haram but also } \\
\text { thoyib..." (Informant WH) }\end{array}$ \\
\hline & $\begin{array}{l}\text { Informants did not question the way } \\
\text { the vaccine was administered but }\end{array}$ & $\begin{array}{l}\text { "In Islam, there are clear rules for using medicinal or food ingredients from halal } \\
\text { sources." (Key Informant } \mathrm{AB} \text { ) }\end{array}$ \\
\hline & $\begin{array}{l}\text { were concerned over vaccine } \\
\text { content and the consequences for } \\
\text { the body }\end{array}$ & $\begin{array}{l}\text { "Halal is undoubtedly mandatory for everything consumed. But my choice not to use } \\
\text { vaccines was not because of that only, but because I felt that there was no benefit from } \\
\text { vaccines." (Informant } \mathrm{HN} \text { ) }\end{array}$ \\
\hline & & $\begin{array}{l}\text { "To the point where as a treatment we are still in the standard of not using elements that } \\
\text { are haram or najis." (Key informant } \mathrm{AB} \text { ) }\end{array}$ \\
\hline \multirow[t]{2}{*}{ Environmental factors } & Influence of media & $\begin{array}{l}\text { "Actually, there are many cases because of immunization, but the television or the media } \\
\text { they rarely reported the cases. But if on the internet, we can see the pro or con news so } \\
\text { we can decide for ourselves." (Informant DW) }\end{array}$ \\
\hline & Influence of anti-vaccine lobby & $\begin{array}{l}\text { "My child often became sick after being vaccinated. I started looking for information, } \\
\text { also through the internet, then I found this Facebook group and became a member about } \\
\text { a year ago, even I was appointed as an admin in the group." (Informant HN) }\end{array}$ \\
\hline
\end{tabular}

ernment policies were not transparent. Increasing the community's knowledge related to vaccines took place through training on immunization of health workers in each primary health care, expecting that health workers could provide a good immunization education to the community. Also, it was found that some informants were well-informed regarding vaccines and about the schedule of immunization and international targets related to vaccines. Furthermore, they were also often exposed to media published by WHO. In this study, the informants' lack of trust in the government has created a negative perception of government policies regarding immunization and became one factor that encouraged informants to dismiss vaccination.

The informants' perception was also influenced by the media, health workers, and anti-vaccine scientists. Culturally, from the informants' statements, the influence of the surrounding environment, including those closest to them, was influential in influencing informants' deci- sions to reject or accept vaccines. This phenomenon is especially evident for less-educated informants.

In terms of informants' knowledge about vaccination, they all know about the national vaccination schedule recommended by the Indonesian Pediatrics Association (Ikatan Dokter Anak Indonesia/IDAI). The perception was also affected by information acquired through social media, health workers, and anti-vaccine scientists. As a result, a perception that vaccination would not guarantee children immunity against diseases could be prevented by immunization. ${ }^{26}$ Also, they perceived that their children's health status would not be affected by their immunization status. In other words, as a spokesperson on the government immunization program stated, health workers' tasks within the community were not only to deliver the immunization as scheduled but also to distribute health information and to put straight the disinformation about immunization.

The role of religious scholars, especially in the Islamic 
religion, is significant in rejecting vaccines. All informants who are Muslim believe that it is obligatory to pay attention to the halal ingredients used for their children, including drugs and vaccines. However, halal and another requirement for consuming something was the thoyib factor, e.g., the quality and usefulness.

Islam believers will have an interest in vaccine safety issues. Mynors, et al.,27 in their study, found that Jews and Muslims groups in Royal England had concerns about the pork component that could be contained in vaccines. Additionally, Orthodox Christians in the Netherlands and the Amish sect in the United States of America are religious communities well-known for their refusal to vaccinate to prevent disease, which is consistent with the concept of "origin of disease, the need for preventive practice and health-seeking behavior".

In this case, media communication was represented by the messages delivered and received in the news that can cause negative or positive sentiments about vaccines. These include mass media, electronics, and social media that trigger and influence individual vaccination refusal decisions. Informants thought that media reporting on television and in newspapers on vaccines' benefits and risks was not balanced. They assumed that the media only informed the public of the benefits of the vaccine all this time. On the other hand, the risks posed and those adversely affected by the vaccine were rarely reported. Social media such as the internet provide more balanced information, so informants assumed could get the actual news and information about vaccines. The information gathered can be the basis and reference for rejecting or receiving vaccinations.

Most informants, getting in touch, getting acquainted, and joining the anti-vaccine community began with an unpleasant experience with medical treatment and immunization. Consequently, they try to determine whether other people have the same experience and perceptions to support each other and share information. As well as seeking information from people around them, the informants with a higher level of education also looked for information from books, the opinions of leaders and scientists, and social media. The anti-vaccine group lobby's influence has been shown to affect informants who already have doubts about vaccines. The doubt itself happened to informants with higher and lower education levels in affirming their decision to reject the vaccine. What distinguishes this situation is the way to find information that confirms the decision. Most of the informants considered vaccines to have no benefits and risk health because they have many side effects. This perception was formed because the informant received knowledge and influence from various sources, including Facebook, where information with anti-vaccine sentiments was often uploaded.
This study's results are in line with the results of Smith, et al.,28 in Atlanta, Georgia (USA) in evaluating the relationship between parents' beliefs about vaccines and the decision to reject vaccines. Parents who reject vaccination have concerns about vaccine safety and thereby assume that there is little benefit from vaccination. ${ }^{28}$ A study conducted by Rahmawati and Umbul,29 in Krembangan, Surabaya (Indonesia) revealed the same results. Nearly two-thirds $(65 \%)$ of respondents stated the reason for the incompleteness of primary immunization was fear of side effects of immunization. ${ }^{29}$

The informants' beliefs and prevention behavior who chose natural treatments and avoided chemical drugs also modified the informants' perception that vaccines containing chemicals had more risks than benefits. Besides, the religious determinant that requires the vaccines to be halal creates distrust of the reliability of the source of production and the supply. This determinant also becomes a barrier to informants receiving the vaccine. Cultural factors and the habit of following the people's pattern around or the people closest who reject the vaccine have more power to influence informants with low education levels. Informants with higher education levels were looking for various reference sources to convince themselves of the vaccines' reliability, not just following general instructions.

The analysis was conducted more clearly to understand the real reason the informant refused vaccination. Interaction of the determinants that influenced vaccine rejection behavior played a role in influencing and ultimately forming the informants' perceptions of vaccines and diseases that can be prevented by immunization. In this study, the informants formed perceptions that the vaccines were dangerous and not beneficial. Also, they believed that the healthy lifestyle they led was sufficient to protect their children from susceptibility to disease. They assumed that diseases that can be prevented by immunization were not something serious or to be feared; thus, vaccination was not needed.

\section{Conclusion}

This study found that knowledge, health and prevention behavior beliefs, religion, culture, and government policies play a role in forming the informants' perceptions of vaccines and risk factors. Factors of vaccination program design and reliability of vaccine-producing sources were inhibiting factors for informants to receive vaccines. Determinants of the media communication, the experience with vaccines, the role of health workers, and the anti-vaccine group lobby strengthened informants' attitude who initially doubted vaccines, causing them to reject vaccines eventually. 


\section{Abbreviations}

AEFI: Adverse Events Following Immunization; GAVI: Gerakan Anti Vaksinasi dan Imunisasi (Movement against both vaccination and immunization); RAP: Rapid Assessment Procedure; SAGE: Strategic Advisory Group of Experts; WHO: World Health Organization.

\section{Ethics Approval and Consent to Participate}

Before data collection, informed consent has been given by all the informants and key informants. When the study took place, there was no obligation for ethical clearance for graduate public health students theses.

\section{Competing Interest}

The author declares that there are no significant competing financial, professional, or personal interests that might have affected the performance or presentation of the work described in this manuscript.

\section{Availability of Data and Materials}

All datasets generated or analyzed in this study are currently available at the request to the University of Indonesia, by contacting Dwi Meilani (dwi.meilani@gmail.com) of the Ministry of Health, Republic of Indonesia.

\section{Authors' Contribution}

DM, EM, and HP participated in developing the protocol, design and analytical framework for the study, contacting informants, testing research instruments, collecting data, analyzing data, and contributing to the writing and analyzing manuscripts. IJH and YP contributed to the up dated literature review and correction of the manuscript. SR participated in the literature review and read the final manuscript, final data analyses, and contributed to the manuscript \& writing. All authors then discussed the results and contributed to the creation of the manuscript. HP approved the final manuscript and all other authors have read and approved this manuscript.

\section{Acknowledgment}

We would like to thank the study informants from Facebook Group GAVI and Facebook Group Stop Vaccine for their willingness to participate in this study.

\section{References}

1. World Health Organization. Fact sheet: measles; 2019 [cited 2019 Dec 17].

2. Ministry of Health Republic of Indonesia. Situasi imunisasi di Indonesia (the situation of immunization in Indonesia). Jakarta: Ministry of Health Republic of Indonesia; 2016. p. 6.

3. World Health Organization. Immunization coverage-fact sheet no. 378; 2015.

4. Ministry of Health Republic of Indonesia. Profil kesehatan 2014 (Health Profile 2014); 2014.

5. Dubé E, Gagnon D, Nickels E, Jeram S, Schuster M. Mapping vaccine hesitancy-country-specific characteristics of a global phenomenon. Vaccine. 2014 [cited 2020 April 25]; 32 (49): 6649-54.

6. Yufika A, Wagner AL, Nawawi Y, Wahyuniati N, Anwar S, Yusri F, et al. Parents' hesitancy toward vaccination in Indonesia: a cross-sectional study in Indonesia. Vaccine. 2020 [cited 2020 April 25]; 38 (11): 2592-9.

7. Mnookin S. The panic virus: a true story of medicine, science, and fear. New York: Simon \& Schuster; 2011.

8. Dube E, Vivion M, and MacDonald NE. Vaccine hesitancy, vaccine refusal and the anti-vaccine movement: influence, impact and implications. Expert Review of Vaccines. 2015 [cited 2020 April 25]; 14 (1): 99-117.

9. Larson HJ, Jarrett C, Eckersberger E, Smith DMD, Paterson P. Understanding vaccine hesitancy around vaccines and vaccination from a global perspective: a systematic review of published literature, 2007-2012. Vaccine. 2014; 32 (19): 2150-9.

10. Benecke O, and DeYoung SE. Anti-vaccine decision-making and measles resurgence in the United States. Global Pediatric Health. 2019 [cited 2020 April 25]; 6: 1-5.

11. Kata A. Anti-vaccine activists, web 2.0, and the postmodern paradigm-an overview of tactics and tropes used online by the anti-vaccination movement. Vaccine. 2012 [cited 2020 April 25]; 30 (25): 3778-89.

12. Kelly L, Jenkinson C, and Ziebland S. Measuring the effects of online health information for patients: item generation for an e-health impact questionnaire. Patients Education and Counseling. 2013 [cited 2020 April 25]; 93 (3): 433-8.

13. NapoleonCat. Facebook users in Indonesia-April 2020. Napoleon Sp.zo.; 2020.

14. Syiroj ATR, Pardosi JF, and Heywood AE. Exploring parents' reasons for incomplete childhood immunization in Indonesia. Vaccine. 2019 [cited 2020 April 25]; 37 (43): 6486-93.

15. de Oliveira JF. The effect of the internet on the patient-doctor relationship in a hospital in the city of Sao Paulo. Journal of Information Systems and Technology Management. 2014 [cited 2020 April 25]. 11: 327-44.

16. Wahyunarni YI, Ahmad RA, and Triratnawati A. Persepsi masyarakat terhadap imunisasi campak di Kabupaten Sleman (community perceptions of measles immunization in Sleman Regency). Berita Kedokteran Masyarakat. 2016 [cited 2019 Dec 17]. 32 (8): 281-6.

17. World Health Organization. Report of the sage working group on vaccine hesitancy. Strategic Advisory Group of Experts (SAGE); 2014.

18. Farhikhtah A, Hohfeld L, Schmall A, Ahimbisibwe M, Saliu I, Hachhethu K, et al. Rapid assessment procedures formative research approach used to design a mobile-technology enhanced social and behavior change communication nutrition strategy in Nigeria (P16-05319). Current Developments in Nutrition. 2019 [cited 2020 April 25]; 3 (Suppl 1).

19. Holdsworth LM, Safaeinili N, Winget M, Lorenz1 KA, Lough M, Asch $\mathrm{S}$, et al. Adapting rapid assessment procedures for implementation research using a teambased approach to analysis: a case example of patient quality and safety interventions in the ICU. Implementation Science; 2020 [cited 2020 April 25]; 15: 12.

20. Wardoyo EH, Syahrizal BM, Ferdiana A. Rapid assessment procedures untuk manajemen puskesmas. Madjalah Kedokteran Indonesia. 2011 [cited 2020 April 25]; 61 (2): 68-75.

21. World Medical Association. WMA declaration of Helsinki-ethical prin- 
ciples for medical research involving human subjects (2013 Revision); 2018.

22. Tolley EE, Ulin PR, Mack N, Robinson ET, Succop SM. Qualitative methods in public health: a field guide for applied research second edition. San Francisco: Jossey-Bass A Wiley Brand; 2016.

23. Hackett A, Strickland K. Using the framework approach to analyze qualitative data: a worked example. Nurse Researcher. 2019 [cited 2020 April 25]; 26 (2): 8-13.

24. Jessiman PE, Campbell R, Jago R, Sluijs EMFV, and Birch DN. A Qualitative study of health promotion in academy schools in England. BMC Public Health. 2019 [cited 2020 April 25]; 19: 1186.

25. Furber CM. Framework analysis: a method for analysing qualitative data. African Journal of Midwifery an Woman's Health. 2010 [cited 2020 April 25]; 4 (2): 97-100.
26. Kementrian Kesehatan Republik Indonesia. Buletin Surveilans PD3I \& Imunisasi; 2020. p. 11.

27. Mynors G. Informed choice in medicine taking: drugs of porcine origin and their clinical alternatives: an introductory guide. Medicines Partnership. 2004 [cited 2021 February 4].

28. Smith PJ, Humiston SG, Marcuse EK, Zhao Z, Dorell CG, Howes C, et al. Parental delay or refusal of vaccine doses, childhood vaccination coverage at 24 months of age, and the health belief model. Public Health Rep. 2011 [cited 2020 April 25]; 126: 135-46.

29. Rahmawati AI, Umbul C. Faktor yang mempengaruhi kelengkapan imunisasi dasar di Kelurahan Krembangan Utara (factors affecting completeness basic immunization village district of North Krembangan). Jurnal Berkala Epidemiologi. 2014 [cited 2020 April 25]; 2 (1): 59-70. 